\title{
Bioremediation Potential of Bacillus licheniformis in Heavy Crude Oil Polluted Soil
}

\author{
Yahya M. Al-Wahaibi, Biji S. Shibulal, Saif N. Al-Bahry, Abdulkadir E. Elshafie, \\ Sanket J. Joshi, Ali S. Al-Bemani
}

\begin{abstract}
Bioremediation is an eco- friendly approach for environmental crude oil cleans up. In this study, 20 different Bacillus species were isolated from heavy crude oil contaminated soil. The strain which showed higher growth at high concentration of crude oil (3\%) was selected for the study. The isolate was identified as Bacillus licheniformis by 16S rDNA sequencing and the genetic sequence was submitted to NCBI GenBank under accession no. KP119115. Under aerobic condition, it was found that the isolate degraded heavy crude oil to $63 \%$ compared to that of the control by GC-MS analysis. The ability of the isolate to grow at $3 \%$ heavy crude oil indicated the capability of Bacillus licheniformis to degrade heavy oil.
\end{abstract}

Keywords-Bioremediation, Bacillus licheniformis, heavy crude oil.

\section{INTRODUCTION}

Increase in energy demands and extensive exploration of new oil fields will result in environmental pollution with crude oil [1]. There are inhabitant microbes present in the soil capable of biodegrading crude oil. Using microbes for bioremediation is the preferred method since the alternative methods like incineration leads to toxic compound [2]. There are numerous microbes capable of biodegrading crude oil, but researches done earlier proved the efficiency of microbes adapted to a similar condition are more efficient [3]. The different strategies that can be used for bioremediation include introducing nutrients and oxygen into the soil (biostimulation), or through inoculation of an enriched mixed microbial consortium into the soil (bioaugmentation) [4]. In the present study, the potency of Bacillus licheniformis to be used in bioremediation was determined.

\section{MATERIALS AND METHODS}

\section{A. Collection of soil samples}

Soil samples contaminated with heavy crude oil was collected aseptically from Oman oil fields and stored at room temperature until use.

Manuscript received December. 14, 2015.

Y. M. Al-Wahaibi and A. S. Al-Bemani are with Petroleum and Chemical Engineering Department, Sultan Qaboos University.

B.S. Shibulal, S. N. Al-Bahry, A. E. Elshafie and S. J. Joshi are with Biology department, Sultan Qaboos University.

\section{B. Isolation of Bacillus spp.}

Spore forming Bacillus spp. were isolated by boiling the soil samples in distilled water for $30 \mathrm{~min}$, culturing the microbes in LB media aerobically at $40^{\circ} \mathrm{C}, 160 \mathrm{rpm}$ and spread plating the supernatant on Bushnell Haas $(\mathrm{BH})$ agar media plated with heavy crude oil. The isolate which showed maximum growth in $\mathrm{BH}$ agar media was selected for the study.

\section{Identification of the isolates}

The isolates are identified by $16 \mathrm{~S}$ rDNA sequencing using universal primers, $27 \mathrm{~F}$ and 1492R. The amplification reaction was performed on a total volumeof $25 \mu \mathrm{L}$ containing: $12.5 \mu \mathrm{L}$ master mix (Taq DNA polymerase, dNTP mix and $\mathrm{MgCl}_{2}$ ), 9.5 $\mu \mathrm{L}$ doubledistilled $\mathrm{H} 2 \mathrm{O}, 1 \mu \mathrm{L}$ extracted DNA and $1 \mu \mathrm{L}$ of each primer. PCR amplification was performed with initial denaturation step at $94^{\circ} \mathrm{C}$ for 3 min followed by 35 cycles of 1 min denaturation step at $94^{\circ} \mathrm{C}, 2$ min annealing step at $53^{\circ} \mathrm{C}$ and 2 min elongation step at $72^{\circ} \mathrm{C}$, and a final extension step at $72^{\circ} \mathrm{C}$ for 7 min using a thermal cycler (Applied Biosystem). The PCR products were detected in $1.5 \%$ agarose gel electrophoresis. The PCR products were purified using QIAquick PCR purification kit (QIAGen) and sequenced using 3130 XL Genetic Analyzer (Applied Biosystem, Hitachi). The genetic sequence was submitted to NCBI GenBank.

\section{Effect of concentration of heavy crude oil on growth of the isolate}

The effect of heavy crude oil concentration on the growth of the isolate BS10 was studied by inoculating in $\mathrm{BH}$ media with $1-3 \%$ heavy crude oil and incubating at $40^{\circ} \mathrm{C}$ and $160 \mathrm{rpm}$ aerobically. The growth of the isolate was measured spectrophotometrically at an optical density (OD) of 660nm for a period of seven days and the $\mathrm{pH}$ variation in the media was studied.

\section{E. Heavy crude oil biodegradation study}

The biodegradation of heavy crude oil by the isolate BS10 was measured using GC-MS. The isolate was incubated in $1 \%$ heavy crude oil in $\mathrm{BH}$ media for a period of 12 days. The biodegraded oil was extracted with hexane : dichloromethane $(1: 1)$.

\section{RESUlts AND DiscUSSION}

Twenty different isolates belonging to genus Bacillus were isolated from heavy crude oil contaminated soil collected from Oman oil fields. Five of the isolates showed considerable 
growth in $\mathrm{BH}$ agar medium. The isolate which showed maximum growth was selected for the study. Many different Bacillus sp. Have already been reported to degrade crude oil (Fig.1) [5-11].

The isolate was identified by $16 \mathrm{~S}$ rDNA sequencing and submitted under accession number KP119115 as Bacillus licheniformis strain BS10.



Fig.1. The growth characteristics of the strain BS10 in 3 different concentrations of heavy crude oil

There was no significant effect of different concentrations of heavy crude oil on the growth of the isolate. Statistical analysis was performed using MINITAB 14. It was observed that $\mathrm{F}=$ $3.11 ; \mathrm{p}>0.05$.

The GC- MS analysis of the biodegraded heavy crude showed a gradual decrease in the total fraction of the crude oil along the time, day 3, 6, 9 and 12 [5, 6, 12-16].

It was shown that the total decrease in $\mathrm{HC}$ fractions was $63 \%$ compared to that of a control (BH media with heavy crude oil) (Fig. 2).

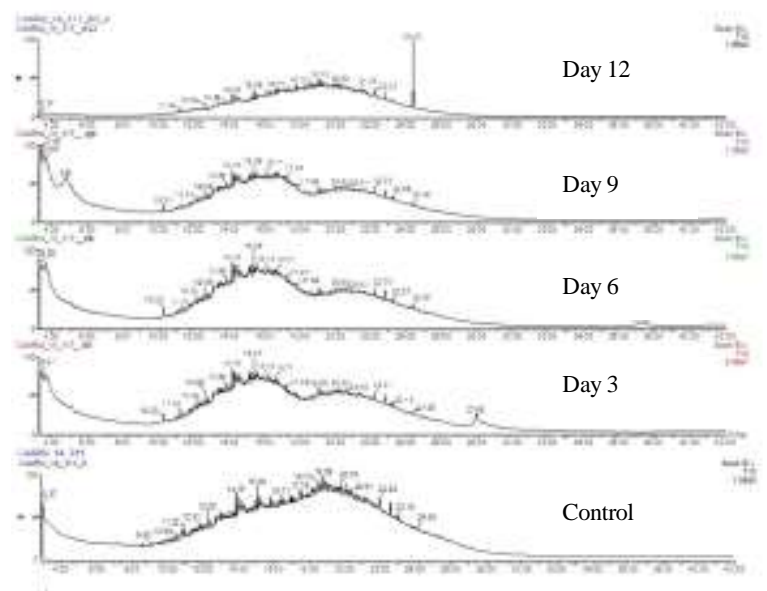

Fig. 2. GC-MS analysis of the biodegraded heavy crude oils

\section{CONCLUSION}

The potential of the isolated Bacillus strain BS10 in degrading heavy crude oil is evident from the study and can be recommended to use for bioremediation and elimination of crude oil pollutant from the environment.

\section{ACKNOWLEDGMENT}

The authors wish to acknowledge the Central Analytical and Applied Research Unit at the Sultan Qaboos University for GC-MS analysis.

\section{REFERENCES}

[1] B. Shibulal, S. N. Al-Bahry, Y. M. Al-Wahaibi et al., "Microbial Enhanced Heavy Oil Recovery by the Aid of Inhabitant Spore-Forming Bacteria: An Insight Review," The Scientific World Journal, 2014, 12 (2014). http://dx.doi.org/10.1155/2014/309159

[2] R. Margesin, "Potential of cold-adapted microorganisms for bioremediation of oil-polluted Alpine soils," International Biodeterioration \& Biodegradation, 46, 3-10 (2000).

http://dx.doi.org/10.1016/S0964-8305(00)00049-4

[3] I. M. Head, and R. P. Swannell, "Bioremediation of petroleum hydrocarbon contaminants in marine habitats," Current Opinion in Biotechnology, 10(234-293), (1999). http://dx.doi.org/10.1016/S0958-1669(99)80041-X

[4] E. Seklemova, A. Pavlova, and K. Kovacheva., "Biostimulation based bioremediation of diesel fuel: Field demonstration," Biodegradation, 12(311-316), (2001).

[5] U. J. J. Ijah, and L. I. Ukpe, "Biodegradation of crude oil by bacillus strains 28A and 61B isolated from oil spilled soil," Waste Management, 12(1), 55-60 (1992).

http://dx.doi.org/10.1016/0956-053X(92)90009-8

[6] R. Hao, M. Lv, and A. Lu, "Biodegradation of crude oil in soil by Bacillus subtilis SB-1," Current Topics in Biotechnology, 6, 49-55 (2011).

[7] C. M. Ouoba LI, Diawara B, Traore AS, Jakobsen M, "Degradation of African locust bean oil by Bacillus subtilis and Bacillus pumilus isolated from soumbala, a fermented African locust bean condiment," J Appl Microbiol(95), 868-873 (2003).

[8] T. N. Nazina, D. S. Sokolova, A. A. Grigoryan et al., "Geobacillus jurassicus sp. Nov., a new thermophillic bacterium isolated from a high temperature petroleum reservoir, and the validation of the Geobaccilus species," Systematic and Applied Microbiology, 28, 43-53 (2005). http://dx.doi.org/10.1016/j.syapm.2004.09.001

[9] L. Wang, Y. Tang, S. Wang et al., "Isolation and characterization of a novel thermophilic Bacillus strain degrading long-chain n-alkanes," Extremophiles, 10(347-356), (2006). http://dx.doi.org/10.1007/s00792-006-0505-4

[10] T. Kato, M. Haruki, T. Imanaka et al., "Isolation and characterization of long-chain-alkane degrading Bacillus thermoleovorans from deep subterranean petroleum reservoirs," Journal of Bioscience and Bioengineering, 91(1), 64-70 (2001). http://dx.doi.org/10.1016/S1389-1723(01)80113-4

[11] A. S. R. Claudia Duarte da Cunha, Gina V. Sebastián, Lucy Seldin, Irene von der Weid, "Oil biodegradation by Bacillus strains isolated from the rock of an oil reservoir located in a deep-water production basin in Brazil," Appl Microbiol Biotechnol, 73, 949-959 (2006). http://dx.doi.org/10.1007/s00253-006-0531-2

[12] R. S. Al-Wasify, and S. R. Hamed, "Bacterial Biodegradation of Crude Oil Using Local Isolates," International Journal of Bacteriology, 2014, 8 (2014). http://dx.doi.org/10.1155/2014/863272

[13] A. D. Venosa, and X. Zhu, "Biodegradation of crude oil contaminating marine shorelines and freshwater wetlands," Spill Science \& Technology Bulletin, 8(2), 163-178 (2003). http://dx.doi.org/10.1016/S1353-2561(03)00019-7

[14] D. Dasgupta, R. Ghosh, and T. K. Sengupta, "Biofilm-mediated enhanced crude oil degradation by newly isolated Pseudomonas species," ISRN biotechnology, 2013, (2013).

[15] W. Xing-Biao, Q. C. Chang, N. a. Yong et al., "Degradation of petroleum hydrocarbons (C6-C40) and crude oil by a novel Dietzia strain," Bioresource Technology, 102, 7755-7761 (2011). http://dx.doi.org/10.1016/j.biortech.2011.06.009

[16] H. Feitkenhauer, R. Müller, and H. Markl "Degradation of polycyclic aromatic hydrocarbons and long chain alkanes at $6070{ }^{\circ} \mathrm{C}$ by Thermus and Bacillus spp,” Biodegradation, 14(6), 367-372 (2003). http://dx.doi.org/10.1023/A:1027357615649 